\title{
PENGARUH CRAVING DALAM PENCAPAIAN KONDISI CLEAN AND SOBER PECANDU NAPZA
}

\author{
Leo Seno Pranoto
}

Yulianti Dwi Astuti

Universitas Islam Indonesia

\begin{abstract}
Craving in many cases can bring a recovery diug addict return to an active drug addict again. This research aimed b comprehend the craving process that influence the drug addict to achieve the condilion called clean and sober. Data were gathered from 4 subjects who have been experiencing problem with drug addiction which reside in Yogjakarta and 1 informan who has been working as their counsellor for these past 5 years. Intenview and observation were used to coliect data.

According to the data obtained, this research was able to identify some findings: Category of craving was consisted of eight themes: definition of craving, the forming of craving condition, condition to active drug addict, condition to passive drug addict, trigger-subject interaction, trigger-object interaction, sublimation-positive factor, sublimation-negative factor. There were conditions which always emerge $h$ answers of all subjects especially in category relapse, clean and sober, and the craving. This condition was (personal) self control
\end{abstract}

Keywords: Craving, clean and sober, drug addict

\section{Pengantar}

Dewasa ini permasalahan NAPZA telah menjadi fenomena yang semakin mengkhawatirkan, bukan saja bagi sekelompok orang tertentu tetapi Juga bagi seluruh masyarakat dunia, tidak terkecuali Indonesia. Permasalahan NAPZA telah menyentuh seiuruh lapisan masyarakat, dari kalangan atas sampai bawah, dari masyarakat umum sampai kaum terpelajar.

Berdasarkan data BNN (Mabes Polri, September 2003), terlihat bahwa penyalahgunaan NAPZA tahun 1999-2003 sebagian besar dilakukan oieh siswa di tingkat pendidikan SLTP dan SLTA4635 dari 5081 kasus. Rentang usia tersebut merupakan saat-saat di mana pembentukan identitas diri terjadi sehingga kadang terjadi penyimpangan dalam upaya pencarian identitas tersebut. Masih menurut data BNN, Yogyakarta pada tahun 2003 menempati posisi delapan besar dalam kasus penyalahgunaan NAPZA. Hal tersebut menunjukkan bahwa di kota yang menyandang predikat sebagai kota peiajar yang penduduknya sebagian besar memiliki tingkat pendidikan tinggi dengan pemikiranpernikiran yang kritis dan tajam tetap bisa menjadi korban NAPZA. Fenomena yang disajkan dalam data BNN tersebut dikatakan beium mewakiti data yang sebenarnya tentang banyaknya korban-korban NAPZA. Hal ini dikarenakan adanya fenomena gunung es, jika ada satu orang korban yang terungkap maka sebetulnya masih ada sepuluh orang korban yang tidak bisa diketahul keberadaannya.

Berbagai upaya untuk mengurangi tingkat penyalahgunaan masalah NAPZA ini telah banyak dilakukan baik oleh pemerintah maupun lembaga-lembaga non pemerintah (NGO/LSM) yang peduli dengan permasaiahan NAPZA Badan Narkotika 
Nasiona| (2003) mengemukakan tiga cara yang bisa ditempuh untuk mengurangi penyebarluasan penyalahgunaan NAPZA, yaitu supply reduction, demand reduction, dan harm reduction. Supply reduction merupakan suatu cara dalam mengurangi persediaan NAPZA. Hal ini tindakan pencegahan lebih diarahkan pada tindakan hukum terhadap proses produksi dan pendistribusian NAPZA pada konsumen. Demand reduction merupakan suatu cara untuk mengurangi permintaan akan NAPZA. Usaha ini lebih dititikberatkan pada faktor intrapersonal dan interpersonal yang mempengaruhi perilaku penyalahgunaan NAPZA. Cara ketiga yailu harm reduction merupakan cara untuk mencegah dampak yang lebih buruk lagi dalam hal penyalahgunaan NAPZA, memastikan bahwa penyakit-penyakit yang menyertai penyalahgunaan tidak menyebar lebih luas (mengurangi penyebaran virus, penyakit, atau infeksi lain). Akan tetapi usaha-usaha yang telah dilakukan tersebut pada kenyataannya belum mampu untuk menyelesaikan secara tuntas permasalahan penyalahgunaan NAPZA.

Jika membicarakan masalah NAPZA maka tidak akan terlepas dari individu yang menyalahgunakan obat/zat ini. Mereka bisa dianggap sebagai korban dari permasalahan yang ditimbulkan akibat penggunaan NAPZA. Mereka sering disebut sebagai addict atau pecandu. Pecandu adalah orangorang yang merasa tidak bisa hidup tanpa NAPZA dalam kehidupan mereka, bahkan untuk beraktivitas secara wajar pun mereka membutuhkan NAPZA (Gordon, 1999)

Permasalahan yang dialami seorang pecandu tidak hanya timbul ketika masih aktif mengkonsumsi NAPZA, tetapi juga muncul ketika mencoba untuk sembuh dari kecanduannya (berhenti menggunakan obat-obatan). Banyak masalah yang harus ditanggung pecandu dalam perjalanannya untuk sembuh. Wicaksono (Hidayat, 2003) menyebutkan bahwa pecandu yang berobat kepadanya hampir semuanya sud ah menjadi pecandu lebih dari dua tahun, apabila kurang dari dua tahun mereka belum ingin sembuh. Menurut Wicaksono, kendala terberat dart para pecandu adalah adanya craving, yaitu perasaan kangen untuk kembali menggunakan NAPZA. Keinginan untuk sembuh $100 \%$, tetapi perasaan kangen untuk kembali menggunakan NAPZA $95 \%$, sehingga kemungkinan untuk sembuh hanya $5 \%$ (Kedaulatan Rakyat, 14 Desember 2003).

Ketergantungan (adiksi) terhadap NAPZA tidak sama seperti penyakit-penyakit lain yang telah dikenal. Hawari (2002) mengatakan bahwa dari 2400 penderita penyalahguna NAPZA yang dirawat (di rumah sakit) dari tahun 1997-1999 terdapat 293 yang dirawat ulang di rumah sakit $(12,21 \%)$. Jika diasumsikan bahwa angka rawat inap tersebut sebagal angka relapse (kekambuhan) maka dapat dilihat bahwa terdapat peluang bagi seorang mantan pecandu untuk kembali menjadi seorang pecandu aktif walaupun telah mendapat perawatan atau terapi medis.

Jika melihat hal-hal dl atas maka dapat dikatakan bahwa sebenamya tidak ada jaminan bahwa seorang pecandu yang memiliki keinginan untuk sembuh dapat mencapai tujuan tersebut. Bahkan begitu banyaknya tempat-tempat rehabilitasl juga tidak ada yang dapat menjamin bahwa seorang pecandu akan terus teriepas darl ketergantungannya. Dapat dikatakan bahwa terdapat ketidakpastian dalam diri mantan pecandu dalam mencapal suatu kondisi normal di masa depannya. Ketidakpastian ini sangat erat hubungannya dengan kebebasan para pecandu dari ketergantungannya terhadap NAPZA.

Masih menurut Hawari (2002), penyebab kekambuhan dari 293 orang tersebut dlsebabkan oleh beragam faktor; 171 orang karena pengaruh teman $(58,36 \%)$, 68 orang karena craving $(23,21 \%)$, dan 54 orang disebabkan faktor stres $(18,43 \%)$. Dilhat dari data tersebut craving merupakan penyebab kedua terjerumusnya kembali para mantan pecandu dalam proses kesembuhannya.

Craving menjadi suatu faktor penting yang harus diketahui oleh seorang pecandu atau individu yang menganggap kecanduan sebagai sesuatu yang mudah untuk 
dihilangkan atau disembuhkan. Kesembuhan yang dikenal dalam dunia pencandu adalah suatu kondisi menuju clean and sober atau dapat diartikan sebagai bersih dan normai, bersih dalam artian bahwa seorang pecandu sudah tidak menggunakan NAPZA sama sekaili dan waras bisa diartikan bahwa seorang pecandu telah mengalami keseimbangan secara psikis. Seorang pecandu yang berupaya untuk sembuh sesungguhnya harus berusaha untuk memperbaiki komponenkomponen yang teiah rusak dalam kehidupannya, tidak hanya fisik, namun juga mental, sosial, dan spiritual. Oleh karena itu pecandu harus terus berjuang melawan faktor craving ini yang akan selalu ada daiam kehidupannya bahkan mungkin sampai mati. Tidak akan ada kata sembuh bagi seorang pecandu, yang ada hanyalah usaha untuk tetap clean and sober(bersih dan normal).

Adanya berbagai kendala tehadap kehidupan seorang pecandu terutama dalam melepaskan diri dari jerat obat-obatan terlarang menimbulkan kesulitan bagi seorang pecandu untuk meraih apa yang diinginkan dalam mencapai kondisi ciean and sober di masa mendatang; dan juga menimbulkan kesulitan bagi orang lain untuk memahami diri seorang pecandu daiam upaya untuk menolong dirinya dalam mempertahankan kondisinya yang lepas dari ketergantungan terhadap NAPZA.

Tampaknya kondisi-kondisi di atas yang nantinya akan menuju suatu bentuk kepastian akan clean and soberdipengaruhi oleh kondisi mental (proses mental) mereka sebagai suatu individu yang unik. Berdasarkan hal-hal tersebut maka penelitian tentang NAPZA ini mengambil fenomena tentang craving yang dialami individu sebagal seorang pecandu atau sebagal seorang recovery addict dalam mempertahankan kondisi clean and sober sepertl yang mereka harapkan.

Penelitian Ini bertujuan untuk memahami proses menuju kesembuhan (clean and sober) yang terjadi pada diri seorang pecandu dalam perjalanan hidupпya menuju ke masa mendatang di seia-sela terdapatnya halangan faktor craving yang mereka aiami sebagai faktor kedua terbesar yang menyebabkan kembalinya seorang recovery addict menjadi seseorang dengan ketergantungan NAPZA (pecandu aktif).

\section{Dasar Teori}

Smith (1976) menyebutkan bahwa narkotika adalah zat-zat (obat) yang dapat mengakibatkan ketldaksadaran atau pemblusan dikarenakan zat-zat tersebut bekerja mempengaruhi susunan saraf pusat. Dorongan penyalahgunaan narkotika ini diiatari oieh berbagai alasan baik secara pribadi, sosiai, maupun medis.

Smith (1976) menyebutkan bahwa narkotika adalah zat-zat (obat) yang dapat mengakibatkan ketidaksadaran atau pembiusan dikarenakan zat-zat tersebut bekerja mempengaruhi susunan saraf pusat. Dorongan penyalahgunaan narkotika ini dilatari oleh berbagai aiasan baik secara pribadi, sosial, maupun medis.

Chaplin (2000) mengatakan bahwa drug addiction (kecanduan obat) diartikan sebagai penggunaan obat bius sebagai kebiasaan dengan disertai ketergantungan fisik maupun psikis. Pecandu NAPZA adalah orang yang seolah-olah tidak bisa hldup tanpa NAPZA. Mereka memakainya sangat sering bahkan sampai menggunakan NAPZA untuk menyeiesaikan semua masalah. The World Health Organization (Franken, 2002) mendefinisikan drug addiction sebagai suatu tingkat keracunan periodik atau kronis yang disebabkan konsumsi obat-obatan yang berulang-uiang. Secara sederhana seorang pecandu adaiah seorang pria atau wanita yang kehidupannya dikendalikan oleh NAPZA.

WHO dan UNDCP (McKim, 2003) menjeiaskan bahwa drug craving merupakan keinginan untuk mengalami kembali pengalaman menggunakan zat psikoaktif. Keinginan ini menjadi semakin besar pada seseorang yang memiliki kemungkinan besar menjadi pecandu. Robbinson (McKlm, 2003) menjelaskan bahwa craving merupakan perwujudan pemikiran di mana akan menjadi semakin kuat dengan adanya 
pengulangan pemakaian suatu obat-obatan karena berhubungan dengan sensitivitas pada bagian otak tertentu. Mantan pecandu walaupun setelah beberapa tahun berhenti menggunakan obat-obatan (NAPZA) tetap berada pada resiko tinggi untuk relapse (kembali menggunakan) dan hal ini sering terpacu oleh stimulus yang dhubungkan dengan pemakaian obat.

Clean dan sober sebenarnya mengacu pada apa yang dinamakan kesehatan. Definisi kesehatan menurut WHO sejak tahun 1984 juga telah mengalami perubahan definisi yaitu yang semula hanya mencakup tiga aspek (sehat dalam arti fisik, psikologik, dan sosial) menjadi 4 aspek dengan ditambahkannya 1 aspek lagi yaitu spiritual/agama (Hawari, 2004).

Clean secara harafiah berarti bersih. Clean merupakan kondisi di mana seorang pecandu sudah tidak lagi mengkonsumsi NAPZA. Kondisl ini biasanya menyertal diri seorang recovering addict (pecandu dalam penyembuhan/pemullhan). Sedangkan sober secara harafiah berarti waras dan Kewarasan. Mereka yang menggunakan NAPZA pada dasarnya menjadi tldak waras d bawah pengaruh NAPZA karena perilaku mereka tidak lagi menunjukkan kehadiran akal sehat. Kata sober digunakan dakam bahasa inggrís untuk menunjukkan pada pecandu yang tidak lagi menggunakan NAPZA(YAKITA, 1999).

\section{Pertanyaan Penelitian}

Bagalmana proses menuju kesembuhan (clean and sober) yang tejadi pada diri seorang pecandu dalam perjakanan hidupnya menuju ke masa mendatang di sela-sela terdapatnya halangan faktor craving?

\section{Metode Penelitian}

Penelitian ini merupakan penelitian sosial yang menggunakan metode pendekatan kualitatif dengan mengambil desain penelitian studi kasus. Untuk penelitian ini dipilh subjek tertentu sesual dengan ketepatan konteks penelitian yaltu hanya dibatasi pada pecandu narkotika yang hidup dalam lingkungan masyarakat luas (bukan dalam tempat rehabilitasi). Alasan pemilihan karakter subjek ini karena perilaku untuk menggunakan kembali obat-obatan (craving) dapat muncul dan dapat dilakukan tanpa penghalang (misalnya peraturan instituși dalam rehabilitasi). Subjek penelitian sebanyak empat orang yang seluruhnya merupakan pecandu narkotika yang berdomisili di kota Yogyakarta. Keempat subjek merupakan individu yang mempunyai masalah dengan ketergantungan terhadap NAPZA khususnya narkotika selama lebih dari dua tahun.

Subjek pertama $(\mathrm{H})$ merupakan seorang laki-laki berusia 28 tahun yang memillki masalah ketergantungan narkotika sejak menginjak kelas 1 SMP dikarenakan faktor pergaulan. Subjek berasal dari keluarga broken home (terjadi perceraian pada kedua orang tuanya). Sebelum mengalami masalah dengan NAPZA, subjek mempunyai prestasi akademik yang baik ketika SD, yaitu selalu menempati peringkat satu. Subjek merupakan pendatang di kota Yogyakarta sejak memasukl perguruan tinggi di salah satu universitas swasta. Aktivitas subjek sampal dengan peneitian dilakukan adalah kuliah dan aktif dalam kegiatan organisasi atau komunitas yang berperan di b|dang NAPZA

Subjek kedua (T) merupakan seorang laki-laki berusia 25 tahun. Subjek memiliki masalah ketergantungan NAPZA sejak berada pada kelas 2 SMPdikarenakan faktor pergaulan dan terdapatnya masalah dalam keluarga. Subjek merupakan penduduk asli kota Yogyakarta. Pendidikan terakhir subjek adalah Diploma 3 di salah satu perguruan tinggi swasta di Yogyakarta. Aktivitas seharihari subjek adalah tergabung dalam komunitas yang menangani permasalahan NAPZAdan HIV diYogyakarta.

Subjek ketiga (A) merupakan laki-lakl berusia 27 tahun dan merupakan penduduk asli kota Yogyakarta. Subjek telah memiliki masalah dengan ketergantungan NAPZA selama 11 tahun dikarenakan faktor pergaulan. Subjek memiliki prestasi di bidang keagamaan ketika SD. Pendidikan terakhir 
subjek adalah S1 di bidang teknik mesin dari salah satu perguruan tinggi swasta d Yogyakarta. Aktivitas subjek adalah bekerja pada suatu event organizer dan aktif dalam komunitas yang bergerak di bidang penanggulangan bahaya NAPZA di Yogyakarta.

Subjek keempat ( $V$ merupakan lakilaki berusia 35 tahun. Subjek merupakan pendatang di kota Yogyakarta dan telah memiliki ketergantungan dengan NAPZA sejak kelas 2 SMP dikarenakan rasa ingin tahu terhadap NAPZA. Pendidikan terakhir subjek adalah SMA. Aktivitas subjek saat ini adalah aktif dalam komunitas yang bergerak di bidang NAPZAdan HIV diYogyakarta.

Selaln keempat subjek penelitian, untuk melengkapl data penelitian penelit juga mengumpulkan data yang berasal dari informan. Informan merupakan seorang wanita berusla sekitar 45 tahun yang berprofesi sebagal dosen di salah satu unlversltas di Yogyakarta dan sebagal konselor masalah ketergantungan NAPZA bagi keempat subjek penelitian. Informan telah berperan sebagal konselor bagi individu yang memiliki masalah terhadap ketergantungan NAPZA sejak tahun 1999. Informan telah membantu masalah ketergantungan NAPZA pada subjek penelitian dalam kurun waktu 5 tahun terakhir.

Lofland dan Lofland (Moleong, 2002) mengatakan bahwa sumber utama dalam penelitian kuafitatif adalah kata-kata, dan tindakan merupakan data tambahan seperti dokumen dan lain-lain. Sumber-sumber data tersebut dicatat melalui catatan tertulis atau melalui perekaman video atau kaset, pengambilan foto, atau film. Untuk dapat memperoleh gambaran dan pengetahuan mendalam tentang craving yang terjadi pada diri seorang pecandu maka metode yang dirasa tepat untuk dapat memperoleh informasi tentang hal tersebut adalah wawancara dan observasi.

\section{Wawancara}

Metode wawancara digunakan untuk menyelidiki pengalaman, perasaan, motif, serta motivasi darl orang-orang dalam suatu keadaan tertentu (Hadi, 2000). Teknik wawancara yang diterapkan adalah wawancara seml terstruktur. Wawancara jenis ini penelitl mengajukan pertanyaanpertanyaan secara lebih bebas dan leluasa, tanpa terikat oleh suatu susunan pertanyaan yang telah disiapkan sebelumnya.

Berikut ini pedoman umum dalam melaksanakan wawancara dengan subjek: (1) Bera pa lama subjek menjadi pecandu dan bagaimana blsa menjadi pecandu; (2) Apakah subjek pernah mengalami relapse, bagaimana hal itu bisa terjadi; (3) Bagaimana pengaruh craving dalam kondisi clean and sober, dan (4) Bagalmana subjek memaknal kondisi clean and sober.

Pedoman wawancara di atas digunakan untuk menggali informasi tentang hal-hal yang terjadi pada dirl seorang pecandu yang meliputi: (a) Life history: Lamanya menjadl pecandu, prestasi masa lalu, pandangan tentang kehldupan keluarga, proses terjadinya relapse, hal yang mempengaruhi relapse; (b) Craving: Definisi craving, proses terjadinya kondisi crawing, mengatasi kondisl craving; (c) Clean and Sober: Pemahaman terhadap kondlsl clean and sober, hambatan dalam pencapaian, perubahan perilaku yang terjadi sebelum dan sesudah clean and sober, pencapaian kondisi clean and sober.

\section{Observasi}

Metode observasi yang digunakan adalah metode observasl terlibat pasif di mana dalam observasI tersebut peneliti tidak terlibat dalam kegiatan yang dilakukan oleh indivldu yang dlarnati. Koterlibatan peneliti hanya terbatas pada keberadaannya dalam wilayah aktivitas yang diwujudkan dalarn kegiatan yang diwujudkan oleh tindakantindakannya (Suparlan dalam Patllima, 2005). Metode ini Juga sering dikatakan sebagai metode observasi nonpartisipan. Sebelum observası dilaksanakan peneliti menentukan tempat-tempat mana saja yang akan didatangi dan mempersiapkan agendaagenda penelitian untuk memudahkan mencatat poin-poin yang seklranya harus 
dicatat dan diamati. Observasi dilaksanakan selama wawancara dengan subjek.

Proses analisis data dalam penelitian kualitatif akan menentukan dalam pencapaian hasil dari penelitian, dalam hal ini melibatkan tiga komponen utama yaitu (1) reduksi data; (2) sajian data; (3) penarikan kesimpulan serta verifikasinya (Miles dan Huberman dalam Sutopo, 2002). Ketiga komponen tersebut akan saling berhubungan dan berinteraksi dalam kegiatan pengumpulan data penelitian

Hasil yang didapat akan dikoding sesuai dengan pendapat Strauss dan Corbin (Poerwandari, 1998) yang membagi langkah koding menjadi tiga bagian yaitu koding terbuka memungkinkan untuk mengidentifikasi kategori-kategori, propertiproperti, dan dimensi-dimensi. Koding aksial dilakukan dengan mengorganisasi data dengan cara ban melalui dikembangkannya hubungan-hubungan di antara kategorikategori, atau di antara kategori dengan sub kategori-sub kategori dibawahnya. Tahap terakhir yaitu koding selektif, melalui mana peneilit menyeleksi kategori yang paling mendasar, secara sistematis menghubungkannya dengan kategorikategori lain, dan memvalidasi hubungan terse but.

\section{Hasil Penelitian dan Pembahasan}

Berdasarkan wawancara yang dilakukan, diperoleh 33 tema yang disimpulkan dalam dua kategori yaitu pemahaman diri dan pemahaman sosial. Pemahaman diri dibagi menjadi lima sub kategori yaitu latar belakang pemakaian, relapse (pemakaian kembali), clean anu sober, craving (drug craving), dan kontrol diri. Subkategori latar belakang pemakaian dibagi menjadi tiga tema yaitu latar personal, latar perilaku, dan latarprestasi. Sub kategori relapse (pemakalan kembali) dibagi menjadi dua tema yaitu faktor personal dan faktor craving. Sub kategori clean and sober dibagi menjadi sebelas tema yaitu pemahaman fisik, pemahaman psikis, perubahan kognitif, perubahan emosional, perubahan behavioral, kondisi pencapaian clean and saber, hambatan faktor intemal, hambatan faktor craving, pencapalan dan stabilitas Kondisi secara personal, pencapalan dan stabilitas kondisi dengan aktivitas positif, dan faktor pencetus internal. Subkategori craving dibagi menjadi tujuh tema yaitu definisi kondisi, pembentukan kondisi craving, kondisi temadap pecandu aktif, kondisi terhadap pecandu pasif, trigger (stimulus) terhadap craving, faktor penetral atau pengalih positif terhadap craving, dan faktor penetral atau pengalih negatif terhadap craving. Subkategori kontrol diri hanya terdapat satu tema yaitu kontrol diri personal.

Pemahaman sosial dibagi menjadi empat subkategori yaitu latar belakang pemakaian, relapse (pemakaian kembali), clean and sober, dan craving. Sub kategori latar belakang pemakaian pada kategori pemahaman sosial terdapat satu buah tema yaitu latar belakang pemakaian secara sosial. Subkategori relapse dibagi menjadi tiga tema yaitu latara interaksi soslal, latar interaksi objek, dan latar interaksi masalah. Subkategori clean and sober dibagi menjadi empat tema yaitu hambatan faktor ekstemal, pencapaian dan stabilitas kondisi dengan lingkungan isolasi, pencapaian dan stabilitas kondisi dengan lingkungan pendukung, dan faktor pencetus eksternal Subkategorl craving secara sosial terdapat satu buah tema yaitu trigger(stimulus) Interaksi objek.

Terdapat berbagai peristiwa yang akan menyertai kondisi ketergantungan pada diri seorang pecandu. individu yang memiliki ketergantungan akan NAPZA (menjadi seorang pecandu) akan memasukl suatu kondisi pemulihan dan kesembuhan yang dikenal sebagai kondisi clean and sober. Kondisi menuju ke arah kesembuhan ini tidak selalu terjadi pada semua pecandu karena ada beberapa hal yang mepengaruhi pencapaian kondisi ini. Faktor pemahaman. hambatan, dan pencetus merupakan hal-hal yang mempengaruhi pencapaian awal kondislini.

Menu rut data yang telah didapat dapat dijelaskan bahwa dari jatar belakang pemakaian NAPZA secara personal, awai dari pemakaian NAPZA ini secara personal dikarenakan oleh dorongan-dorongan dari 
dalam diri masing-masing individu seperti keinginan untuk mencari jati diri atau karena pembawaan karakterpribadi.

Latar belakang perilaku yang menyebabkan individu beresiko untuk memiliki permasalahan dengan ketergantungan NAPZA (menjadi seorang pecandu) adalah dikarenakan hal-hal seperti perilaku coba-coba, suka mencari tantangan dan sensasi, dan rasa Ingln tahu. Latar belakang soslal yang teriadi pada Indlvldu dengan ketergantungan NAPZA didapatkan bahwa terdapat beberapa faktor sosial yang melatarbelakangi kondlsi tersebut di antaranya faktor pergaulan/teman, orang tua, dan masalah. Menurut data yang terkumpul dari subjek penelitian didapatkan bahwa tiap subjek memilikl latar prestasi dalam kehidupannya sobelum menjadi seorang pecandu balk prestasi dalam bidang akademik maupun dalam bidang keagamaan.

Relapse merupakan suatu kondisi di mana seorang pecandu yang telah mencoba untuk sembuh dari kecanduan kembali menggunakan NAPZA. Kondisi relapse ini dipengaruhi oleh lima hal yaitu faktor personal, faktor craving, faktor latar interaksi sosial, faktor latar interaksi objek, dan faktor latar interaksi masalah. Faktor personal yang menyebabkan pemakalan kembali NAPZA terdiri dari beberapa kejadian meliputi ketidakberdayaan terhadap kecanduan dan NAPZA, ketidaktahuan apa yang harus dilakukan untuk menghentikan kecanduan terhadap NAPZA, ketidakmampuan untuk menolak NAPZA belum memiliki kontrol yang bagus, belum munculnya niat untuk berhenti, adanya kejenuhan terhadap keseharian, dan dlderitanya suatu penyakit tertentu. Faktor craving merupakan suatu faktor yang terungkap pada keempat subjek penelitian dlmana keseluruhan subjek menyebutkan bahwa craving merupakan faktor yang melatarbelakangl kondlsi relapse. Menurut keempat subjek penelitian latar interaksi soslal yang menyebabkan kondlsi relapse antara lain adalah dikarenakan faktor teman dan lingkungan. Latar interaksi objek yang melatarbelakangi relapse adalah karena melihat NAPZA dan perlengkapannya, dan dikarenakan telah terpengaruh oleh NAPZA itu sendiri. Munculnya suatu masalah juga terindikasikan sebagai sebuah faktor yang menyebabkan kondisi relapse dlmana hal tersebut dikelompokkan ke dalam latar Interaksi masalah.

Berdasarkan informasi yang diperoleh darl subjek penelitian terdapat sebuah kondlsi yang terjadi pada dirl seorang pecandu yang dikelompokkan ke dalam kategori ciean and sober yang terdli dari lima belastema:

a. Pemahaman fisik. Pemahaman clean dan sober secara fisik diungkapkan oleh keempat subjek penelitian sebagal suatu kondisi tan pa memakai NAPZA.

$$
\begin{aligned}
& \text { Abstinence, maksudnya ga pake drug } \\
& \text { apapun(H) }
\end{aligned}
$$

Kita benar-benar bersih tanpa napza jonis apapun $(T)$

Bisa beraktivitas tanpa make dulu (A)

Bersth itu ya ga pake (V)

b. Pemahaman psikis. Pemahaman secara psikis ini diungkapkan oleh ketiga subjek (subjek $H, A$,dan V). pemahaman ini meliputi adanya perubahan pola pikir, emosi dan perilaku, dan kewarasan

... sober itu buat aku bisa merubah pola pikir dan perilaku. Bisa membedakan mana yang baik dan buruk $(H)$

\section{Soberitu khan kewarasan (A)}

Mungkin emosinya agak normal, pola plklr den semuanya berubah,... Menurut saya pribadi dengan ga pake secara ga langsung pemikiran kta jadi pulih(v)

c. Perubahan kogniffi, meliputl munculnya kemampuan berplkir, adanya perubahan sifat, dan munculnya kesadaran diri. 
Dulu karena mind set-ku masih junkie maka semuanya mau diselesaikan secara instan. Ada masalah harus selesai instan......drug, lagi senang....pesta drug. Tapi sekarang aku mulai belajardan belajar. $(H)$

......... Jadi bisa beraktivitas seperti orang nomnal, bisa berfikir dengan sedjkitjemih, .......(A)

d. Perubahan emosional, meliputi kontrol emosi, adanya perubahan sifat, dan munculnya kesadaran diri.

Jadi ga gampang marah, dulu kalo minta uang ilu ga kirakira tapi kalo sekarang jadj lebih mikir kalo minta uang, jadi lebih sungkan kalo minta uang( $V)$

e. Perubahan behavioral, meliputi adanya perubahan sifat, perilaku membuang peralatan NAPZA, berhenti untuk mencari NAPZA, kemampuan membawa diri/menjadi supel, pola hidup lebih teratur, dan munculnya kesadaran untuk menaati peraturan.

\section{barang-barang mulai aku buang $(H)$}

aku dulu orangnya pendiem, sekarang ga. Duiu ketika masih pake, seandainya ada komunitas banu aku ga bakal mau masuk ke komunitas itu, tapi seandainya ada salah salu aja yang suka mabuk baru mau masuk, biar nyambung aja Jadi perilaku yang utama itu bisa membawa din; jadi yang dulu ga bisa masuk ke komunitas orang lain sekarang bisa, dulu sih membatasi pergaulan $(A)$.

...... Fobih teratur, pola hidupnya juga ga berantakan (V).

Jadi duiu waktu pernah pakaw itu ga ada rasa bersalah dan ga takut melanggar hukum. Tapi kalo sekarang udah mulai tahu peraturan dan berpikir kalo mau melanggar hokum, jadi bener-

\section{benerberubah $(V)$}

f. Kondisi pencapaian clean and sober, meliputi mengalami penurunan craving, kemampuan untuk beraktivitas tanpa menggunakan NAPZA kondisi clean belum tentu sober, pencapalan kondisi sober harus diawali dengan kondisi clean terlebih dahulu, kondisi sober membutuhkan waktu minimal dua tahun clean.

pengalaman saya kalo clean its belum tentu sober. Clean kalo daiam waktu deket pasti tetep goyah. Untuk benerbener sober mungkin butuh 2 sampai 4 tahun, itu bener-bener tidak jamah,dalam arti kaio menurut saya kalo slip itu ya its ok, jadi slip itu udah ga ngefek dalam arti temperamennya ga kembali kaya dulu $(V)$.

g. Hambatan faktor internal, meliputi munculnya masalah, kebingungan akan apa yang akan dilakukan, perasaan nyaman ketika memakai NAPZA, menghindari beban, emosi terkontrol selama memakai NAPZA, dan kondisi emosional yang tinggi.

hambatanku apa ya..........misalnya ada masalah berat, masalah cewek... cinta bertepuk sebelah tangan, misalnya dan sebagainya. Masalah dengan teman lah ...eh terus pikirannya balik jadi junkie lagi terus ngedrug lagi $(M)$

Tapi lebih nyaman kalo pake karena lebih enjoy, lebih lepas dari semuanya, dalam arti ga ada beban pikiran. Kaio saya make emosi saya maiah terkontrol (T).

Terus hambatan yang lain itu seandainya kita ada masaiah atau emosi yangtinggi (A)

h. Hambatan faktor eksternal, meliputi munculnya masalah, adanya tekanan dari lingkungan, dan karena faktor 
teman/komunitas.

Banyak sih dari orang lain bisa. Contohnya ketika ada tamu dari luar kota dan minta ditemenin aku untuk cari barang, maka otomatis aku harus tahu tempat, tapi aku di situ mengalami hambatan, aku ga bisa jamin kaio aku bisanolak $100 \%(\mathrm{~A})$

i. Hambatan faktor craving. Tema ini didapatkan dari kesamaan jawaban dari semua subjek di mana mereka menyatakan bahwa craving merupakan suatu hal yang mempengaruhi kondisi kesembuhan (clean and sober).

Hambatan aku itu ya seperti adanya triggersuges itu, ............(H)

Rasa pengen, ye craving ite terus keluar. Suges itu aja ga ngeliat barang aja bisa keluarapalagi ingeliat orang ( $V$ ).

j. Pencapaian dan stabilitas kondisi secara personal, meiiputi adanya kesadaran diri, adanya keinginan untuk belajar membangun diri, dan adanya niat serta kemauan untuk menghargal hidup.

Dan alhamdulillah saya punya kesadaran of mana kesadaran itu jauh labih besar jika dibandingkan kotika saya pertama kali melakukan treatment secara medis (famakologi). .......melihat dan merasakan untuk membangun diriku sendiri.......... Yang penting nlat dan mau menghargai hidup(H).

k. Pencapaian dan stabilitas kondisi melaiui lingkungan isolasi, meliputi menjauh dari lingkungan komunitas lama atau pindah ke lingkungan baru.

tidak maen ke tempat yang ulicin" dulu....jadi ga maen ke komunitas yang dulu walau bukan berarti kita harus ngelupain komunitas itu, ..... (A)
L Pencapajan dan stabilitas kondis| meialui iingkungan pendukung, meiiputi adanya teman berbagi, adanya perhatian dari keiuarga, orang di sekitar berperan dalam kondisi sober, dan menjadikan lingkungan yang menjadi masaiah menjadi tempat untuk melakukan treatment.

terus ada pematian dari keluarga, terus ada temen untuk berbagl, faktor dari keluarga itu yang paling ged he (A).

m. Pencapaian dan stabilitas kondisi dengan aktivitas positif. Terna ini dldapat berdasarkan kesamaan jawaban dari keseluruhan subjek penelitian. Terna ini meliputi adanya kegiatan positif untuk mengaiihkan craving seperti kerja atau kesibukan lain.

Mengisi hari-hariku dengan kegiatan yang positif. Contohnya dengan mengkritik pemerintah, orang-orang of sekitarku, bikin TA $(H)$

Waktu itu saya pengen bener-bener beresin kuliah dan setelah selesal juga langsung dapat pekerjaan. Saya beresin kulah selama tiga bulan dan wisuda, terus selama dua bulan saya cari kerja dan of bulan kedelapan saja mulai dapat kerja (T).

n. Faktor pencetus clean and sober secara internal, meilputi ketidakinginan untuk menguiangi kehidupan yang dulu, sudah tidak bisa lagl untuk menikmati NAPZA, memperoleh klik untuk berhenti, keinginan untuk membuktikan diri, adanya rasa capek, bosan dan jenuh untuk menggunakan NAPZA, kelnginan diri untuk berhenti, dan munculnya rasa bersalah pada diri.

Udah ga bisa ngerasain pedaw, mabuknya putaw. Temen-temen waktu itu pada pakaw semua, udah pada tepar semua, padajatuh, aku masih aja melek 
sampal akhinya df de pan Masjid itu aku ngerasa dapat "klik" kalo aku harus berhenti $(H)$

aku pengen ngebuktion kalo aku itu bisa hebat di muka kamu $(H)$.

\section{Mungkinjuga karena capek,.... (T)}

Pada keluargaku dan diriku sendiri. Jadf rasa bersalahnya itu kaio dari keluarga itu udah pasti, salahnya gedhe banget. Terus dari diriku sendiri kan kalo aku ngejaianin kehidupan yang berhubungan dengan drug itu kan aku ga maju-maju (A).

o. Faktor pencetus clean and sobersecara eksternal, meliputi kesulitan dalam mendapatkan NAPZA, teman tertangkap dan masuk penjara, adanya keinginan untuk menyelesaikan kuliah. tertangkap oleh polisi, rasa takut keluarga akan menjadl hancur, ketakutan jika tertangkap polisi, dan munculnya rasa bersaiah pada keluarga.

Setelah saya tiga kali tertangkap baru bener-benersadar, $(V)$

Waktu ifu saya pengen bener-bener beresin kuliah dan sefelah seiesai juga langsung dapat pekerjaan. ( $T$

Pada keluargaku dan diriku sendiri. Jadf rasa bersaiahnya itu kaio dari keiuarga itu udah pasti, saiahnya gedhe banget (A)

Kategori craving yang behasil ditemukan bahwa kategori ini terdli dari delapan terna yaltu:

a. Definisi craving. Definisi terhadap craving diperoleh dari kesamaan jawaban seiuruh subjek penelitian yaitu merupakan rasa ingin untuk menggunakan NAPZA.
Suges itu pergerakan aiam bawah sadar, ya .... rasapengen $(H)$

Kaio suges khan rasa ingin

Kalo menurutku suges itu rasa pengen unfuk make iagi. Seumpama kita pake sabu, jadf yang kila tahu itu ritualnya dan rasanya,jadi rituainya dari bikin alat dan proses menuju pemakaian itu masuk dalam ingatan yang ga bisa dilupakan. (A)

Rasa pengen pake dan pengen ngerasain. Jadi kaya terngiang df kepala ini cuman pada saaf merasakan putaw itu nalk nikmatnya, df hidung wanginya kaya apa, fly-nya kaya apa. Ya karena pongen itu. Saking kuatnya efeknya di kepala. (V)

b. Pembentukan kondisi craving. Berdasarkan data yang diperoleh dari keempat subjek diketahui beberapa kondisi pembentukan craving yaitu pertama, craving mulai muncul ketika pertama kali seseorang menggunakan NAPZA; kedua, craving muncul ketika terjadi perilaku penghentian penggunaan NAPZA; ketiga, yang terjadi ketika craving muncul adalah pengingatan kemball akan keuntungan yang didapat dari pemakaian NAPZA (rasa nikmat ketika menggunakan).

Rasa pengen pake dan penger: ngerasain. Jadi kaya terngiang di kepaia ini cuman pada saat merasakan putaw itu naik nikmatnya, di hidung wanginya kaya apa, fly-nya kaya apa. Ya karena pengen itu. Saking kuatnya efeknya di kepala. $(H)$

Yang paing aku rasain paling sakit ketika saya sebelumnya memakai putaw, efep. (T)

Rasa teringat kembali pada saat nikmati enaknya putaw timbul. Jadi kaya femgiang dikepala ini cuman pada saat merasakan putaw itu naik nikmatnya, 
dihidung wanginya kaya apa, fly-nya kaya apa. (N)

c. Kondisi temadap pecandu aktif, meliputi munculnya gejala sakit fisik seperti mual, muntah, dan sakit kepala; dan terjadi perubahan kondisi menjadi sakaw (kesakitan akibat penghentian pemakaian NAPZA).

Kila itu kadang ketemu orang yang sama-sama pake, kalo kita udah lama ga pake, aku llat mukanya ada rasanya kepengen banget, entah fu hanya migren, kalo pemakai putaw biasanya mual dan mungkin sampai muntah. Tapi kalo udah menuju sakaw yang dirasain badan klta, bagi pemakai putaw yang sakit th baglan tulang dan persendlan. Seperti orang romatik. Dan mungkin juga pilek, mata berair. (H)

d. Kondisi terhadap pecandu pasif, meliputi tanpa adanya gejala sakit fislk dan craving memberikan efek terhadap pemikiran (seperti sulit untuk fokus, terjadi pengingatan kembali tentang kenlkmatan pemakalan, dan menguasal20 \% dari pemiklranj.

Kalo fisik ga ada tapi kalo psikis ada. Pslk/snya ya tadi nyerang pikiran dan Imbasnya ko cara berpikir jadi ga bisa fokus.(A)

Waktu pertama kali datang suges itu paling cuma sekitar $20 \%$ memikirkan drug dan yang $80 \%$ mikiryang lain $(H)$

e. Trigger (stimulus) interaksi subjek, hal ini meliputi kemunculan craving ketka datang perasaan bosan, muncul ketika melamun. muncul ketika badan mengalami kelelahan, muncul ketika tidak ada kesibukan yang dilakukan, muncul ketika adanya suatu masalah, dan terdapatnya hubungan timbal balik antara craving dan masalah.

Kadang-kadang rasa $B e T e$ juga bisa fadi trigger. Kało lagi BeTe pongen menghibur dirt, bisa nyaman, dan mind setjunkie, "enaknya ngapain ya, pakaw enaknoh". (H)

Kemaren aja waktu ada kerjaan ït aku suges, karena capek bangot harus lembur, terus mbayangin kalo pake doping duiu pasti rasanya onak bangot. (A)

Seandalnya kita ga ada kegiatan pasti pikirannya akan ko situ, apalagl kalo kita ada uang tapi ga ada keglatan (A)

Karena kalo aku sendiri ketika ada masaiah pasti pertama kall pikiranku iarinya ke situ. Itu saling timbal balik. Jadi kalo aku ada masalah pasti akan suges. Tapl kalo ada suges beium tentu ada masalah. Aku boium bisa nentuin mana yang iebih berat. $(A)$

f. Trigger(stimulus) Interaksi objek, dalam hal ini craving dapat muncul ketika terjadi situasi-situasl sepertl melihat NAPZA, bertemu dengan teman sesama pecandu, mendengarkan musik, menyuntik vitamin pada tubuh sendirf, mendengarkan pembicaraan orang mengenal NAPZA, teringat ritual ketika memakai NAPZA, melihat tempat ketika dahulu memperoleh NAPZA, dan adanya tawaran untuk memakal NAPZA.

.... Akhimya menjurusnya ke silu (pake napza) kalo kotemu tomen-temen lama. Dan kemudlan suges mulai keluar, rasa ingin pun mulai keluar. (T)

Oh, ilu sudah tidak lagi, bahkan kemaren aku sempet nyuntik sendiri, tapi itu vitamin B-komplek karena kebelulan istri temenku perawat of Jakarta dan dia bawa vitamin dalam bentuk amput, bahken temenku itu aku suntikin. Aku udah berani. Tapi itu tetep bikin aku suges. (H)

Saya aja kalo ada temen nawarin bolum lentu bisa nolak kok ( $)$ 
9. Faktor penetral/pengalihan positif. Keempat subjek ketika wawancara memberikan jawaban tentang caracara untuk mengalihkan craving secara positif yang meliputi melakuan kegiatan seperti jalan-jalan (mencari hiburan), mencoba mencari kesibukan, mencoba untuk menenangkan dirl, tidak memfokuskan pada craving, dan menjauhi teman pecandu.

Kalo lagi suges aku muter-muter Jogja sampajenakan.(H)

Pokoknya dibuat berkegiatanlah, itu khan yang diserang pikiran kita jadi harus bisa gimana caranya untuk ngalihin pikiran kita. (A)

Yang pertama its jangan maen ke tempat yang slicin" dulu. Misalnya ada yang cerita kalo semalem habis make, ya jangan didengerin, dibawa sambil lalu aja karena kalo didengerin nanti malah nyambung. Terus yang kedua itu adalah beraktivitas. fiu aja (A)

Karena udah jouh dari temen yang dulu jadi udah ga sering muncul sugesnya (V)

h. Faktor penetral/pengalihan negatif, hal ini meliputi tindakan seperti pemakaian kodein, menghilangkan craving dengan memakal kembali NAPZA, dan melakukan pengobatan pada dokter di mana dengan hal tersebut craving akan menjadi semakin besar.

Masalahnya saya berobat juga ke psikiater. Lha dosis saya malah makin Iama makin tinggi, makanya saya jadj lakul. Menutup sih menulup, lapi setelah berobat suges kita malah makin gedhe. (H)

Dulu kalo lagi suges saya pake kodein $10 \mathrm{ml}$, itu harus supaya ga mual dan muntah kalo lagi suges.(V)
Kalo kangen kelemu orang khan kalo udah ngelial lerus hilang tapi kalo ini harus sampai ngerasain nikmatnya baru ilang. (V)

Terdapat suatu kondisi yang selalu muncul dalam jawaban-jawaban subjek penelitian terutama dalam kategori rolapse, clean and saber, dan craving. Kondlsi ini adalah kontrol diri di mana lebih terarah pada kontrol diri personal. Kondisi kontrol diri ini juga terdapat pada informasi yang diberikan oleh informan. Kondisi kontrol diri personal ini meliputi pengendalian terhadap NAPZA, pengendalian diri, ketahanan ketika harus bertemu dengan teman-teman pecandu, pengendalian emosi, craving hanya muncul tanpa disertal pemakaian kembali NAPZA, kontrol terhadap pikiran, dan munculnya kesadaran dalam diri.

Berdasarkan kategori, sub kategori, dan tema-tema yang diperoleh dari hasil wawancara maka dapat dijelaskan beberapa hal menyangkut pertanyaan penelitian. Pertama, craving memang berperan dalam pencapaian kondisi clean and soberpada diri seorang pecandu. Craving merupakan suatu faktor yang mempengaruhi pencapaian kondisi clean and saber. Hal ini sesuai dengan hasil wawancara seluruh subjek penelitian di mana mereka mengatakan bahwa hambatan dalam mencapai kondisi kesembuhan (clean and saber) adalah karena craving. Craving menjadi faktor yang berpengaruh besar terhadap Kembalinya seorang mantan pecandu untuk kemball mengkonsumsi NAPZA. Ketika seorang pecandu tidak mengetahui cara mengalihkan atau menetralkan craving ini maka pecandu akan kembali pada perilaku pemakaian NAPZA kembali (relapse). Salah satu hal yang bisa menekan faktor craving ini adalah terdapatnya suatu kontrol diri. Kedua, cravingtercipta sebagai hasil dari pemakaian NAPZA di man a craving mulai berada dalam diri seseorang ketika individu tersebut pertama kali menggunakan NAPZAdan telah merasakan keuntungan dari pemakaian tersebut. Ketiga, sesual dengan jawaban subjek yang telah berada pada kondisi sober, 
craving akan mengalami penurunan baik secara kualtas maupun kuantitas ketika seseorang telah berada pada kondisi clean and sober.

Terdapat berbagai cara untuk mengatasi craving yang terjadi pada diri seorang pecandu, antara lain adalah dengan melakukan keglatan-kegiatan positif untuk mengalihkan/menetralkan craving seperti: bekerja, mencari hlburan tanpa melibatkan NAPZA, atau dengan membatasi atau menjauhi lingkungan pecandu. Hal tersebut dilakukan karena croving akan NAPZA tidak akan bisa dihilangkan karena tetap akan berada dalam ingatan seorang pecandu sehingga yang bisa dilakukan adalah meminimalisir efek dari craving terse but.

Proses yang terjadi pada awal kondisi clean and sober akan menuju pada dua bentuk akhlr kondisi seorang pecandu. Kondisi pertama adalah seorang pecandu akan kembali pada perilaku penggunaan NAPZA (relapse), dan yang kedua adalah pecandu akan tetap pada kondisi clean and soberdengan tingkat yang lebih baik. Kondisi pertama (relapse) akan muncul ketika hambatan yang terjadi pada awal kondisi clean and sober tidak mampu diatasi oleh seorang pecandu. Faktor craving inl merupakan suatu permasalahan tersendirl dikarenakan faktor Ini juga muncul sebagal hambatan yang terjadi pada kondisi clean and sober dan menjad hal yang diakul sebagai penyebab pemakaian kembali NAPZA pada keempat subjek. Craving dapat mempengaruhl kondisi kesembuhan dari seorang pecandu. Craving akan masuk ke dalam alam bawah sadar sehingga terkadang akan muncul tanpa disadari oleh seorang pecandu ketika terdapatnya suatu faktor pencetus (trigger). Rasa kangen mengaktifkan kembali ingatan-ingatan (memori) akan keuntungan yang didapat dari pemakaian NAPZA. Hal tersebut akan mengarahkan perilaku untuk menggunakan NAPZA kembali. Penggunaan NAPZA akan dianggap sebagai sesuatu yang menyenangkan sehingga perilaku tersebut akan mengalami pengulangan (operant conditioning).
Kondisi kedua yang akan muncul dalam proses awal kondisi clean and sober adalah suatu kondisi di mana seorang pecandu akan tetap berada dalam kestabilan kondisl kesembuhan (tetap berada pada kondisi clean and sober). Muncul suatu faktor pendukung yaitu kontrol diri sebagai hasll penelitian df mana faktor ini merupakan sebuah kondisi yang akan mengarahkan pada perilaku menghindari pemakaian NAPZA dan mempertahankan dirl pada kodlsi clean and sober.

\section{Penutup}

Berdasarkan hasil peneltian tersebut maka disarankan:

Para pecandu blsa menyadari bahwa craving sangat berpengaruh pada kondisi kesembuhan akan ketergantungan. Bagi Individu yang mempunyal keinginan untuk menyelesalkan permasalahan ketergantungan NAPZA (memutuskan untuk berhenti) disarankan untuk segera mencari cara untuk menekan atau mengalihkan rasa craving ini, antara lain adalah dengan melakukan kegiatan-kegiatan posiltif untuk mengalihkan/menetralkan craving seperti: bekerja, mencari hiburan tanpa melibatkan NAPZA, atau dengan membatasi atau men]auhi lingkungan pecandu.

Masyarakat do sekitar atau orang yang berada d sekltar pecandu dlharapkan dapat mendukung setiap perubahan yang terjadi pada diri seorang pecandu dengan menciptakan lngkungan yang kondusif bagi proses menuju kesembuhan darl seorang pecandu. Lingkungan kondusif ini diperlukan juga untuk bisa mempertahankan kontrol dirl yang telah ada pad a diri seorang pecandu.

Masyarakat harus mulai menganggap bahwa permasalahan ketergantungan NAPZA inl adalah masalah bersama, bukan sekedar masalah salah satu individu atau golongan. Keberhasilan proses kesembuhan dari difi seorang pecandu ditentukan oleh pecandu itu sendiri dan kepedulian lingkungan di sekitar pecandu.

Bagi peneliti selanjutnya yang berminat untuk mengambil topik yang sejenis 

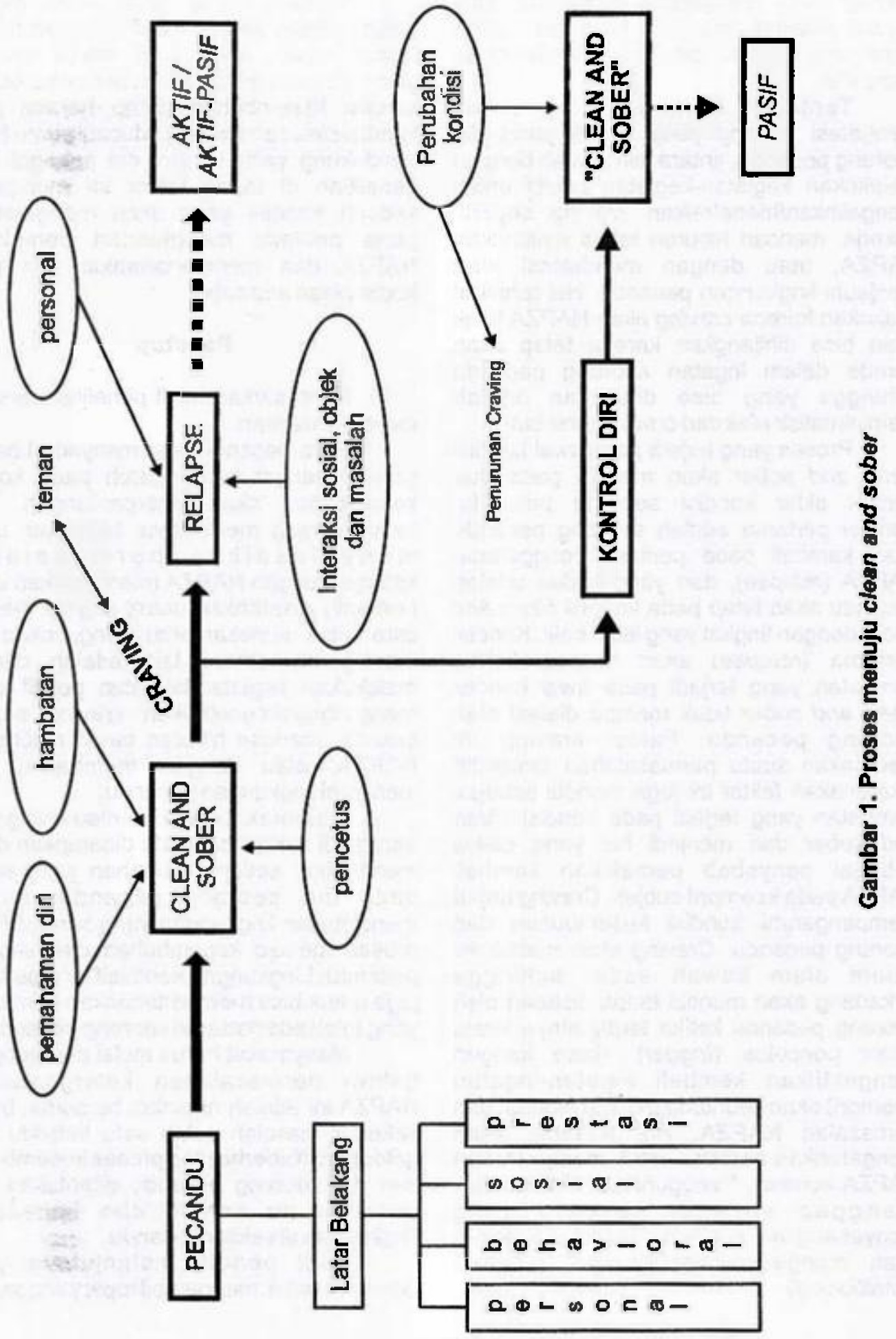
diharapkan untuk meneliti lebih mendalam tentang craving yang terjadi d kalangan para pecandu wanita mengingat subjek penelitan yang dilakukan saat ini adalah pada kelompok pecandu pria. Penelitian sejenis juga sebaiknya dilakukan pada kelompok pecandu di suatu institusi pemulihan (rehabilitasi) untuk melihat respon perilaku terhadap munculnya craving. Selain itu, peneliti yang mengambil subjek pecandu yang masih aktif menggunakan NAPZA agar memperhatikan kondisi subjek penelitian. Kondisi ini menjadi sangat penting dikarenakan akan mempengaruhi jawaban yang akan diberikan. Diajurkan untuk melakukan wawancara ketika kondisi subjek berada pada kondisi normal. Kedekatan secara emosional akan menjadi suatu kunci dalam melakukan penggalian informasi yang dibutuhkan.

Perlu diperhatikan pula untuk melakukan penyamaan persepsi tentang halhal yang akan digali dari diri seorang pecandu sehingga tidak terjadi suatu kesalahan komunikasi yang akan berimbas pada pengolahan data. Bagi penelitian selanjutnya dengan desain sejenis untuk mendasarkan kredibilitas tidak hanya dari segi validitas akan tetapi juga dari segi reliabilitas penelitian.

\section{DAFTAR PUSTAKA}

Anonim. 1999. NancotiosAnonymous. Bogor: Yayasan KTA

Badan Narkotika Nasional. 2003. Perkembangan NAPZA of Indonesia. Jakarta

Franken, RE. 2002. Human Motivation $5^{\text {m }}$ odition. Californla: Wadsworth/Thomson Learning

Gordon, J. 1999. Anda Curiga Dia Memakai NAPZA. Bogor: Yayasan KITA

Hawari, D. 2004. Al-Qur'an: Ilmu Kedokteran
Jiwa dan Kesehatan Jiwa. Yogyakarta: PT. Dana Bhakti Prima Yasa

2003. Penyalahgunaan dan Ketergantungan NAPZA. Cetakan kelima. Jakarta: Gaya Baru

2002. Konsep Agama (Islam) Menanggulangi NAPZA. Jakarta: Dana Bhaktı Prima Yasa

Kellerman, L. (Tanpa Tahun). A Guide for the Family of the Alcoholic. Virginia Beach: Al-Anon Family Group Headquarters, Inc.USA

Martin, G \& Pear, J. 2003. Behavior Modification: What it is and Hoe To Do it. Seventh Edition. New Jersey: Prentice-Hall, Inc.

McKim, W.A. 2003. Drugs and Behavior: An Introduction to Behavior Pharmacology. Fifth Edition. New Jersey: Pearson Education, Inc.

Moleong, L.J. 2002. Metodologl Penelitian Kualitatif. Bandung: PT. Remaja Rosdakarya Offset

Patilima, H. 2005. Metode Penelitian Kualitatif. Bandung: CV. Alfabeta

Patten, M.L. 2000. Understanding Research Mot hods.America: Pyrczak Publishing

Poerwandari, E.K. 1998. Pendekatan Kualitatif Jaiam Penelitian Psikologi. Lembaga Pengembangan Sarana Pengukuran dan Pendidkan Psikologi (LPSP 3): Fakultas Psikologi Universitas indonesia

Sutopo. 2002. Metodologl Penelitian Kualitatif Dasar Teori dan Penerapannya dalam Penelitian. Surakarta: Sebelas Maret University Press 
Gordis, E. 2000. Craving Research: Implications for Treatment. http://www.niaaa.nih.gov/gublications/ ao의, htm, 31/3/2005

Hidayat, L. 2003. Craving NAPZA Berfangsung Seumur Hidup. Harian Kedaulatan Rakyat. Minggu, 14/12/2003. Hal 17. Yogyakarta: Kedaulatan Rakyat.
Subhan, H.M. 2003, Pecandu dan Yang Dibutuhkan. Harian Kedaulatan Rakyat, Selasa, 24/07/2003. Hal 10. Yogyakarta: Kedaulatan Rakyat 